Olena Bulatova, Doctor of Sciences (Economics), Professor, Mariupol State University, 129, Budivelnykiv Ave, Mariupol, 87500, Ukraine, ORCID: 0000-0001-7938-7874;

Angelika Balabanits, Doctor of Sciences (Economics), Professor, Mariupol State University, 129, Budivelnykiv Ave, Mariupol, 87500, Ukraine, ORCID: 0000-0001-8009-119X;

Inna Babyna, Candidate of Economic Sciences (PhD), Associate Professor., Francisk Skorina Gomel State University, 104, Sovetskaya str., 246109 Gomel, Republic of Belarus, ORCID: 0000-0001-6424-4758

\title{
STRATEGIC MANAGEMENT OF COMPETITIVE POSITION OF TOURISM REGIONS
}

The expediency of the tourism region studying as an object of competitiveness management is revealed in the article, the strategic approach to the tourism region competitiveness management reflects the multipurpose nature and multi-vectority of management influence is substantiated, the system of indicators for the tourism region competitiveness assessment is proposed.

Keywords: Tourism Region Competitiveness, Strategic Management of Competitiveness, Tourist Attractiveness of a Region, Tourism Business Activity.

Relevance of research topic. International trade of tourism services has become a truly global socio-economic phenomenon, one of the most influential factors for the countries and regions economies growth. The number of travellers around the world increased by $5 \%$ in 2018 up to 1.4 billion. For the seventh consecutive year, the growth of tourism exports in the world $(+4 \%)$ exceeded the growth of exports of goods $(+3 \%)$ [1]. The governments of the countries are tasked with developing common approaches to balancing the economic benefits from enhancing the tourism industry competitiveness, at the same time effectively developing the tourism potential of the regions, infrastructure and cultural values on which the competitiveness depends. 
Given the market economy globalization in the tourism industry, the problem of ensuring competitiveness at the level of the tourism enterprise as well as at the regional and national levels becomes crucial. The Tourism and Resort Development Strategy for the period up to 2026 has emphasized that «despite its resource availability and endless potential tourism opportunities, Ukraine is currently unable to compete with developed tourism countries». [2].

In conditions when tourism is becoming a leading sector of strategic importance at both national and regional level, an actual problem of theoretical and applied character is the development of strategic tools for the tourism industry for increment of sustainability and productivity of usage of regional competitive advantages: natural, material and technical, infrastructural, institutional, labour resources, etc.

Analysis of recent researches and publications. The theory of strategic management of tourism activity, as well as the regions competitiveness as a component of this process is developing both in the vertical and horizontal plane. A considerable amount of research by domestic and foreign authors is devoted to the issue of implementation of strategic management processes in tourism activities, such as: E. Adelseitova, O. Bartoshchuk, A. Grishchuk, E. Kozlovsky, V. Kucherenko, M. Malskoy, A. Terebukh and others. The development of mechanisms for ensuring the competitiveness of the tourism product and the tourism industry has been studied in the scientific works of domestic and foreign scientists: Y. Alekseeva, V. Bezugla, I. Valentyuk, V. Gulyaev, A. Granberg, L. Davydenko, M. Dolishniy, M. Kabushkin, V. Middleton, V. Fedorchenko, A. Chechel, A. Yaroshand others.

Problems of ensuring the competitiveness of tourism and recreational complexes of the regions were studied by G. Aleinikova, G. Andreeva, N. Golovchenko, P. Gudz, V. Danilchuk, N. Kalkova, N. Kolenda, A. Moklyak, S. Nezdominov, N. Strachkova, L. Cherchyk. However, despite considerable experience, certain aspects of the theory of strategic management of tourism region competitiveness remain to be discussed, namely approaches to defining its essence as an object of competitiveness management, revealing the influence of various factors on the level of competitiveness, the relation between external and internal competitiveness positions of the object.

Formulation of the problem. Based on the above, the purpose of the article is to scientifically substantiate the strategic approach to management of the tourism region competitiveness in the context of global competition, taking into account the peculiarities of domestic tourist destinations and the level of infrastructure development.

Presenting main material. The competitiveness of the country in the international tourism markets is ensured by the effective functioning of each tourism region through the formation of unique tourism capacity, the creation and realization 
of competitive tourism products. The region competitiveness is defined as the ability of each regional system to manage its competitive advantages, to provide rational and efficient deployment of productive forces to ensure sustainable financial and economic standing, maximize benefits, meet objective and subjective needs on the basis of autonomy and self-financing, within existing legislation [3 p. 64].

$\mathrm{N}$. Golovchenko determines the region competitiveness as its ability to «enhance and maintain certain competitive positions in the production and realisation of competitive goods (services) in order to meet the demand of potential consumers in a desired observance of interests of the society as a whole[4].In our previous studies, it was stated that the region competitiveness in terms of its tourist attractiveness should consider its ability to gain competitive advantages over other regions of the country by receiving tourists for a long period [5, p. 36]. Thus, the competitiveness of the tourism region as an economic category represents some relative integral characteristic that reflects the differences of the aggregate tourist product and, accordingly, determines its tourist attractiveness for the consumer.

The strategic goal of the tourism region management as a competitive unit is to ensure its competitiveness for a long period. The tourism region is an open system, so its level of competitiveness is influenced by many factors: interaction of enterprises of different industries (transport enterprises, hotel and restaurant businesses, trade enterprises), market of goods and services conditions and the state of the environment.

A. Anderson identified four determinants that underlie the paradigm of modern dynamic regional development in the context of global competition («C-factors»): competence, culture, communication and creativity. [6].

Strategic management of the tourism region competitiveness is an activity that involves the development and implementation of a strategy for the development of the region, relevant target programs, strategic decisions and measures aimed at enhancing its tourist attractiveness and rational use of tourism capacity.

Strategic management of the tourism region competitiveness is advisable to conduct using an integrated mechanism developed by us (Figure 1), which provides multi-vector of management influence and is ensured by the implementation of management processes of basic mechanisms (proactive, organizational and adaptive).

The mechanism of proactive management of the tourism region competitiveness is a set of interrelated techniques, methods and levers of influence that ensure the formation of strategic intentions for the tourism region development and the development of strategies for ensuring competitiveness on the basis of the analysis of the international and national tourism market conditions. 

strategic intentions for the tourism region development

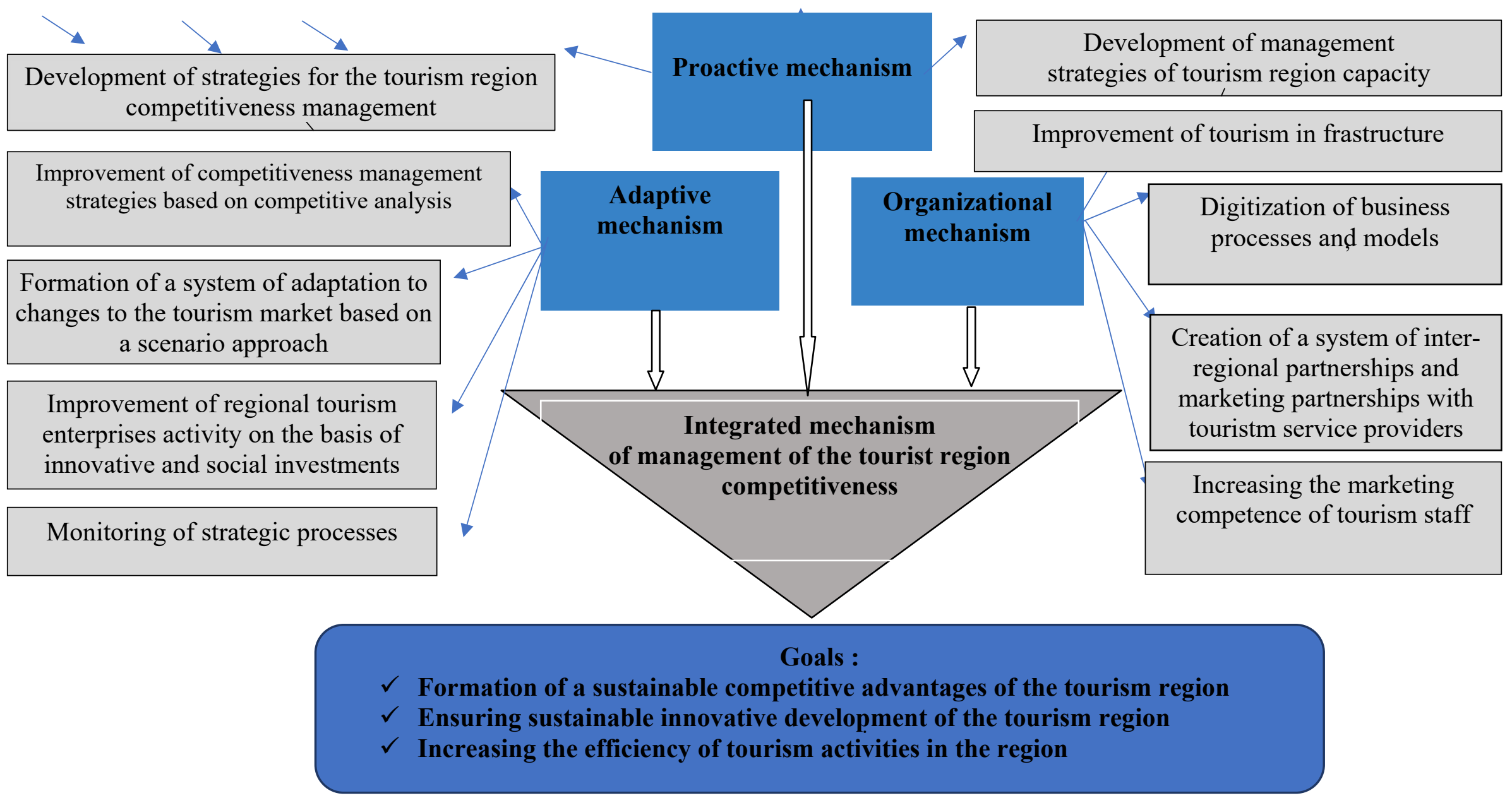

Figure 1. An integrated mechanism for strategic management of the tourism region competitiveness 
The organizational mechanism to ensure the tourism region competitiveness is a sequence of management actions aimed at creating a system of inter-regional partnerships and marketing partnerships with tourism providers, the implementation of digital technologies in business processes in order to increase productivity and improve communication interaction with consumers of services, introduction of innovative and integrative forms of entrepreneurship, ensuring improvement of the professional-qualification level of employees in the tourism industry.

In order to implement an adaptive mechanism in the management process of the tourism region competitiveness, it is necessary to: constantly take into account the uncertainty and risk factor in the changes of the external and internal environment; carry out a comprehensive analysis of different situations (economic, demographic, environmental), strengths and weaknesses of the tourism region capacity; to evaluate the effectiveness of the selected strategic set, determine the level of the tourism region competitiveness and goal achievement.

The tools for strategic management of the tourism region competitiveness are the following: a strategic vision of the region development as a tourism center; mission and strategic goals aimed at creating a unique tourist offer based on the tourism region capacity, ensuring balanced development of the region, building an institutional environment and establishing interregional partnerships; a system of strategies for ensuring the region competitiveness (tourism development strategy in the region, marketing and promotion strategies for the region in domestic and international tourism markets, personnel and financial support strategies, etc.).

The level of the tourism region competitiveness depends on the competitiveness of all its subjects. The tourism region competitiveness is a general feature of its market stability, which is conditioned by the efficiency of utilization of the available resource capacity, the ability of the tourism activity subjects to provide attractive and highquality tourism products, the ability to adapt to the changing competitive environment. Increasing competitiveness at the regional level depends on the business activity of the tourism enterprises themselves, as well as on state and regional policy towards increasing the regional tourist attractiveness.

On this basis, the directions of the tourism region competitiveness assessment are the analysis of indicators that determine:

- tourism business activity of the region (the volume of provided tourism services in the region, financial result of tourism enterprises activity of the region, etc.);

- tourist attractiveness of the region (intensity of tourist flows to the region, regional resource and recreational rating, etc.).

The analysis of competitiveness indicators of tourist regions (Table 1) allowed to conclude that there are significant differences in the tourism business development 
across Ukrainian regions. Leading positions are in the city of Kyiv, Lviv and Odesa regions. The worst positions are in Luhansk, Donetsk, Kirovograd, Volyn, Rivne, Ternopil and Chernihiv oblasts. It is possible to allocate the TOP-5 regions of Ukraine by the largest amount of revenues from the payment of the tourist fee, which came to the local budgets in 2018: the city of Kyiv - UAH 32.9 million $(36.3 \%$ of the total amount); Lviv oblast. - UAH 13.4 million (14.7\% of the total); Odessa oblast - UAH 11.5 million (12.7\%); Zakarpattia oblast - 3, 8 million UAH (4.1\%); Ivano-Frankivsk oblast. - UAH 3.7 million (4.0\%).

It should be noted that some tourist regions, such as Vinnytsia, Ternopil, Chernivtsi and Chernihiv oblasts, do not use their capacity for tourist attractiveness at all, showing low financial results from tourism activity even with considerable natural and recreational resources.

Table 1

\section{Indicators of tourism competitiveness of Ukrainian regions}

\begin{tabular}{|c|c|c|c|c|c|c|c|c|c|}
\hline \multirow[b]{2}{*}{ 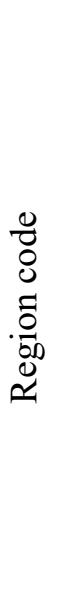 } & \multirow[b]{2}{*}{ Name of oblast } & \multicolumn{5}{|c|}{ Tourism business activity } & \multicolumn{3}{|c|}{$\begin{array}{c}\text { Tourist attractiveness of } \\
\text { the region }\end{array}$} \\
\hline & & 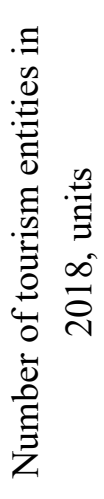 & 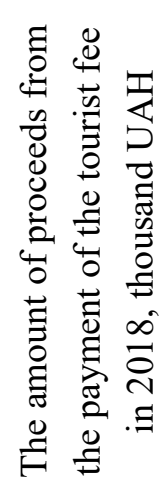 & 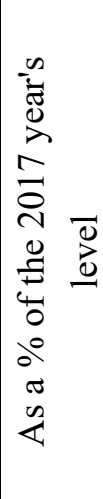 & 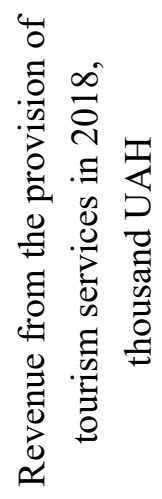 & 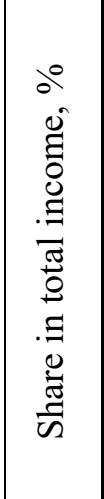 & 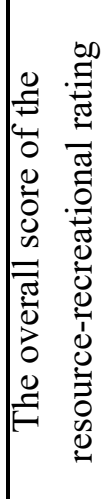 & 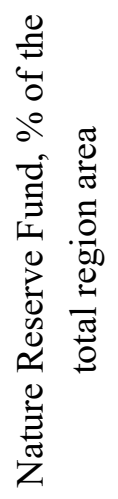 & 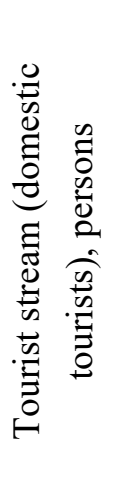 \\
\hline 1 & Vinnytsia & 25 & 483,8 & 122,5 & 17978,4 & 0,08 & 4 & 2,1 & 8360 \\
\hline 2 & Volyn & 19 & 584,6 & 118,9 & 15339,5 & 0,07 & 2 & 6,8 & 5963 \\
\hline 3 & Dnipropetrovsk & 119 & 2523,5 & 121,0 & $\mathbf{3 0 9 3 7 , 8}$ & 0,14 & 2 & 2,8 & 9229 \\
\hline 4 & Donetsk & 31 & 1224,4 & 146,2 & 28498,3 & 0,13 & 1 & 3,5 & 5575 \\
\hline 5 & Zhytomyr & 16 & 544,8 & 120,5 & 4088,5 & 0,01 & 2 & 4,4 & 3359 \\
\hline 6 & Zakarpattia & 28 & 3802,0 & 131,0 & 14580,1 & 0,06 & 2 & 13,8 & 6258 \\
\hline 7 & Zaporizhia & 62 & 3665,9 & 135,2 & 21831,0 & 0,1 & 1 & 2,6 & 17138 \\
\hline 8 & Ivano-Frankivsk & 34 & 3699,4 & 122,4 & 437913,7 & $2,07 \mid$ & 3 & 14,1 & 33572 \\
\hline 9 & Kyiv & 45 & 2326,9 & 149,2 & 20679,4 & 0,09 & 4 & 4,0 & 3320 \\
\hline 10 & Kirovohrad & 13 & 259,3 & 127,5 & 7746,1 & 0,036 & 1 & 0,5 & 1280 \\
\hline
\end{tabular}




\begin{tabular}{|c|c|c|c|c|c|c|c|c|c|}
\hline \multirow[b]{2}{*}{ 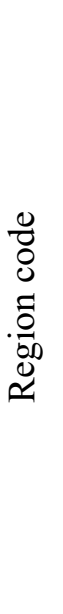 } & \multirow[b]{2}{*}{ Name of oblast } & \multicolumn{5}{|c|}{ Tourism business activity } & \multicolumn{3}{|c|}{$\begin{array}{c}\text { Tourist attractiveness of } \\
\text { the region }\end{array}$} \\
\hline & & 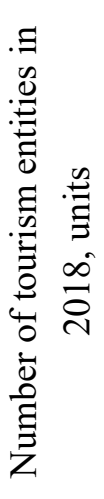 & 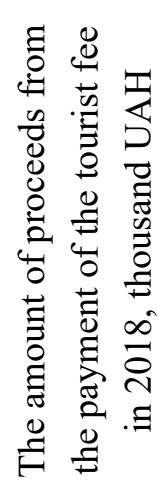 & 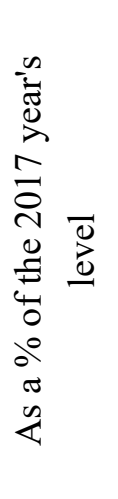 & 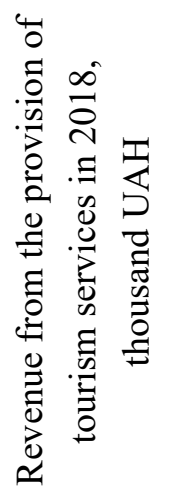 & 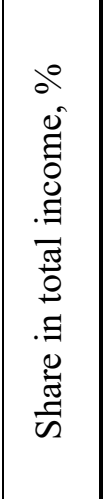 & 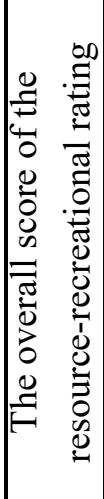 & 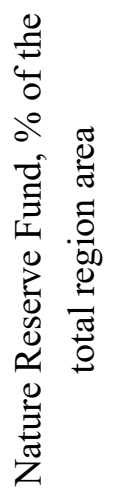 & 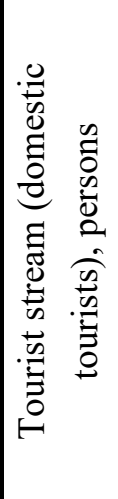 \\
\hline 11 & Luhansk & 8 & 143,9 & 120,9 & 573,1 & 0,002 & 1 & 2,5 & 86 \\
\hline 12 & Lviv & 142 & 13417,6 & 125 & 442823,2 & 2,1 & 4 & 6,8 & 61881 \\
\hline 13 & Mykolaiv & 18 & 1832,6 & 128,2 & 4160,0 & 0,019 & 2 & 3,1 & 948 \\
\hline 14 & Odessa & 135 & 11550,7 & 127,4 & 172028,9 & $\mathbf{0 , 8 1}$ & 4 & 4,6 & 24081 \\
\hline 15 & Poltava & 15 & 1341,0 & 124,5 & 5893,9 & 0,027 & 2 & 4,9 & 2124 \\
\hline 16 & Rivne & 27 & 355,7 & 115,2 & 8458,6 & 0,04 & 2 & 9,0 & 1680 \\
\hline 17 & Sumy & 18 & 332,2 & 114,8 & 7620,8 & 0,036 & 2 & 6,6 & 3128 \\
\hline 18 & Ternopil & 20 & 402,0 & 137,4 & 6344,6 & 0,03 & 2 & 8,9 & 3618 \\
\hline 19 & Kharkiv & 83 & 2979,6 & 119,4 & 40553,1 & 0,19 & 2 & 2,4 & 8326 \\
\hline 20 & Kherson & 16 & 3690,4 & 136,5 & 36123,6 & 0,17 & 2 & 9,7 & 6428 \\
\hline 21 & Khmelnytskyi & 25 & 731,5 & 143,7 & 4322,3 & 0,02 & 2 & 14,8 & 12017 \\
\hline 22 & Cherkasy & 27 & 724,1 & 132,7 & 10018,0 & 0,04 & 2 & 2,9 & 3364 \\
\hline 23 & Chernivtsi & 39 & 527,2 & 125,8 & 21578,1 & 0,1 & 2 & 12,6 & 5050 \\
\hline 24 & Chernihiv & 12 & 599,4 & 134,8 & 2654,4 & 0,01 & 3 & 7,6 & 1102 \\
\hline 25 & City of Kyiv & 856 & 32983,6 & 131,2 & 19706523,1 & $|93,5|$ & 4 & - & 228913 \\
\hline
\end{tabular}

Source: Developed by: $[7,8,9$; based on statistical information on tourism by the Chief Statistics Offices of the oblasts].

Determining the level of tourism regions competitiveness makes it possible to propose measures to improve the activity of tourism enterprises that can solve the problems of tourism industry development in the region, as well as increase the competitiveness of the region in the tourism market of Ukraine.

Conclusion. Thus, we can draw the following conclusions. The tourism region competitiveness is a component of the multi-level economic category «competitiveness» along with the competitiveness of the tourism offer, tourism enterprise, national tourism industry. 
Strategic management of the tourism region competitiveness is the implementation of a concept that combines targeted and integrated approaches to tourism activities at the regional level, which allows to set goals for the tourism region development, to timely determine the existing external opportunities for its development and reserves of tourism and recreational capacity in line with the development and implementation of a system of appropriate strategies.

Assessment of tourism region competitiveness allows to convert its strategy of development into a system of clear set goals and objectives, as well as indicators that determine the degree of achievement of strategic installations in two directions: ensuring business tourism activity and tourist attractiveness of the region.

The proposed mechanism for the tourism region management competitiveness is based on the allocation of problem-oriented outline of management, is targetoriented and allows timely response to changes in the external and internal environment, and thus, is able to ensure a high level of tourism regions adaptability and dynamic conformity between their tourism capacity and competitive position.

The direction of further research may be the development of matrix tools for strategic analysis of tourism regions competitive positions in the system of strategic management of the tourism region competitiveness in both national and international tourism markets. The results of such studies can be useful in identifying priority areas for the tourism region development, based on the improvement of existing and development of new strategies for ensuring sustainable competitiveness.

\section{REFERENCES}

1. International Tourism Highlights, 2019 Editionhttp. Retrieved from: https:// www. tourlib.net/wto/WTO_highlights_2019.pdf.

2. Pro skhvalennia Stratehii rozvytku turyzmu ta kurortiv na period do 2026 roku: rozporiadzhennia Kabinetu Ministriv Ukrainy vid 16 berez. 2017 r. № 168-r. [On approval of the Strategy for the development of tourism and resorts for the period until 2026: the decree of the Cabinet of Ministers of Ukraine of March 16. 2017 № 168-p.]. Retrieved from: https://www.kmu.gov.ua/en/npas/249826501.

3. Bezugla, V. O. (2004). Analiz konkurentospromozhnosti regioniv Ukraïni [Analysis of the competitiveness of Ukrainian regions]. Regional'na ekonomika. Vol 4(34), pp. 64-68.

4. Golovchenko, N.Z. (2008). Formuvannya mekhanizmiv pidvishchennya konkurentospromozhnosti kurortno-rekreacijnogo kompleksu regionu [Formation of mechanisms of increasing the competitiveness of the resort and recreation complex of 
the region]. Avtoreferat disertaciï na zdobuttya naukovogo stupenya kandidata ekonomichnih nauk : spec. 08.00.05. Odesa, Ukraine - pp. 20.

5. Balabanits, A.B. (2019). Upravlinnya konkurentospromozhnistyu turistichnö̈ industrii Ukraïni na mizhnarodnomu rinku turistichnih poslug [Management of competitiveness of the Ukrainian tourism industry in the international tourism services market]. Visnik Mariupol's'kogo derzhavnogo universitetu. Seriya: Ekonomika. Vol. 18. pp. 32-42.

6. Anderson, A. (1991). Infrastruktur zur Entwicklung von Regionen. In: Der Ministerprasident des Landes Schleswig-Holstein. Denkfabrik (ed.) Infrastruktur der Kommunikationsge-sellschaft. Schleswig-Holstein als K-region. Projektgruppe der Denkfabrik Schleswig-Holstein. pp. 16-19.

7. Gerasimenko, V. G., Bedradina, G. K., Galasyuk, S. S. and others (2016) Ocinka turistichno-rekreacijnogo potencialu regionu: monografiya [Evaluation of tourist-recreational capacity of the authorities: a monograph ]. ONEU, Odesa, p. 262.

8. Informaciya shchodo finansovo-ekonomichnih pokaznikiv sferi turizmu ta kurortiv 2017-2019 roki. [Information on financial and economic indicators in tourism and resorts sector] Retrieved from: https://me.gov.ua/Documents/List?lang=ukUA\&id=be44a1a7-69b3-4a77-a86a-447499abcdd6\&tag=Analitika

9. Turistichna diyal'nist' v Ukraïni u 2018 roci. [Tourism activity in Ukraine in 2018]. Retrieved from: http://www.ukrstat.gov.ua/operativ/operativ2019/tyr/tyr_dil/ arch_tyr_dil.htm.

10. CHerchik, L., Mostenec', O. (2016). Mekhanizm zabezpechennya konkurentospromozhnosti rekreacijnoï sistemi regionu : monografiya [ Provision mechanism for competitiveness of the recreational system of the region: a monograph]. Skhidnoevropejs'kij nacional'nij universitet imeni Lesi Ukraïnki, Luc'k, p. 214 